\title{
TREATMENT OF MULTI-FRAGMENT DIAPHYSEAL BONE FRACTURES BY BLOCKING INTRAMEDULLARY OSTEOSYNTHESIS TECHNIQUE (ANALYSIS OF ERRORS AND COMPLICATIONS)
}

\author{
Danylo Halytsky Lviv National Medical University, Lviv, \\ Ukraine
}

Возрастание уровня травматизма и распространенности ортопедической патологии определяет необходимость совершенствования диагностики и лечения повреждений и заболеваний опорно-двигательного аппарата как приоритетного направления развития здравоохранения. Улучшение диагностических возможностей современных методов визуализации состояния костей, суставов и мягких тканей, расширение сферы применения высокотехнологичных малоинвазивных способов остеосинтеза позволят изменить концепцию предоставления ортопедо-травматологической помощи.

Приведенный обзор литературы посвящен актуальности проблемы и анализу структуры травматических повреждений, а также принципиальным преимуществам их лечения методом внутрикостного остеосинтеза, который заключается в том, что, благодаря закрытой репозиции отломков и малому хирургическому доступу вне зоны повреждения, не наносится дополнительная травма тканям в зоне перелома.

Изучены и проанализированы основные ошибки хирургов при выполнении интрамедуллярного блокирующего остеосинтеза. Показано, что лечение пациентов с диафизарными оскольчатыми переломами длинных трубчатых костей должно включать меры по восстановлению анатомических структур травмированного сегмента и функции поврежденной конечности. Установление четких показаний и последовательное предоперационное планирование оперативного вмешательства с тщательным подбором параметров фиксирующих конструкций являются основными факторами, влияющими на качество фиксации отломков, и обеспечивают конечный результат.

Ключевые слова: травма, переломы костей, блокирующий интрамедуллярный остеосинтез, ошибки хирургов, осложнения

The growth of the level of traumatism and the prevalence of orthopedic pathology determine the necessity to advance diagnostics and treatment of injuries and diseases of the musculoskeletal system as a priority trend in the development of health care. Improvement of diagnostic capabilities of modern methods of visualizing conditions of bones, joints and soft tissues, expansion of the scope of high-tech minimally invasive osteosynthesis techniques will change the concept for implementation of orthopedic trauma care.

The proposed literature review is dedicated to the urgency of the problem and analysis of the structure of traumatic injuries, as well as the fundamental advantages of their treatment by the method of intraosseous osteosynthesis, which, due to the closed reposition of fragments and low surgical access outside the damage zone, doesn't cause any additional injury to the tissues in the fracture zone.

The main errors of surgeons when performing intramedullary blocking osteosynthesis have been studied and analyzed. It has been shown that treatment of patients with diaphyseal multi-fragment fractures of the long tubular bones should include measures to restore the anatomical structures of the injured segment and the function of the injured limb. The determination of clear indications and consistent preoperative planning of surgical intervention with careful selection of parameters of fixing structures are the main factors affecting the quality of fixation of fragments and they ensure the final result.

Keywords: trauma, bone fractures, intramedullary osteosynthesis, surgical errors, complications

Novosti Khirurgii. 2019 Mar-Apr; Vol 27 (2): 204-211

The articles published under CC BY NC-ND license

Treatment of Multi-Fragment Diaphyseal Bone Fractures by Blocking

Intramedullary Osteosynthesis Technique (Analysis of Errors and Complications)

V. S. Kozopas

\section{Introduction}

In recent decades, the number of fractures of the long tubular bones of the skeleton has significantly increased due to an increase in severe road traffic injuries and disasters [1, 2, 3, 4]. According to the WHO, by 2020 injuries resulting from an accident will have probably become the third leading cause of death or injury [5, 6, 7]. In recent years, there is a clear tendency to an increase in victims with high-energy injuries $[8,9]$. Their feature is the high proportion of polysystem and multi-organ injuries, which are characterized by severe course, high disability and mortality [10]. In the USA, up to 17 million people suffer from injuries every year, about $1 \%$ of them die, and $2 \%$ become 
disabled [11, 12, 13]. In the structure of primary disability, they steadily occupy the third place, conceding only to diseases of the cardiovascular system and oncological diseases [14]. The number of cases of temporary disability due to injuries has increased by $36 \%$, and makes up 5.3 cases per 100 employees [15]. The peculiarity of injuries of the musculoskeletal system is that they lead to the most pronounced socio-economic losses, as they predominate among young and middle-aged people who have a high labor activity. Recently, the problem of significant losses from injuries has been discussed both at the national level in Ukraine and in the world [16, 17]. According to the Institute of Demography and Social Studies, annual economic losses due to injuries and deaths in Ukraine exceed 10 billion hryvnias, which is $2.5 \%$ of gross domestic product and $1 / 3$ of the cost of health care [16].

An increase in the proportion of injuries in the structure of injuries due to high-energy actions has led to the emergence of a large number of victims with severe injuries of the musculoskeletal system, in which the bone tissue and the surrounding soft tissues suffer over a large area $[18,19]$. Due to the development of technical progress, injuries have changed not only quantitatively but also qualitatively - the number and severity of polytrauma, severe multiple injuries, among which fractures of the long bones of the limbs of mainly comminuted and polyfocal character predominate [20, 21]. The indicated injuries are severely tolerated by victims, depriving them of their ability to move independently for a long time, and are among the main "sources" of unsatisfactory treatment results for injuries of the musculoskeletal system. Among the variety of injuries, it is diaphysial fractures of the long bones that are very common injuries among the population of Ukraine, their number is $48.5 \%$ of all fractures of the long bones, and comminuted and polyfragmental fractures constitute $16.5 \%$ of the fractures of all limb segments [22]. The frequency of diaphyseal fractures of large segments of the lower limbs is more than $26.3 \%$ of the total number of fractures of the long bones, while the greatest number of complications is observed with injuries of the lower limbs - 54.4\%, and slightly less (29\%) with the injuries of the upper limbs. Among all the fractures of the long tubular bones, the diaphyseal femur fractures take the second place and comprise from 10.4 to $23.9 \%$, whereas the fractures of the diaphysis of the bones of the shin constitute up to $45 \%$, remaining the most common among the injuries of the bones of the limbs [23].

It should be noted that the problems of the reparative osteogenesis disorders occurring after diaphyseal fractures of the long bones of the limbs remain relevant. The frequency of this pathology ranges from 2.5 to $18 \%$ [24]. The high material costs of treating patients with slow consolidation, refractures and false joints after diaphyseal fractures are one of the most important aspects of medical and social rehabilitation of patients with such pathology $[25,26.27 .28 .29]$.

\section{Treatment}

At the present stage, the situation with the choice of a conservative or surgical treatment of comminuted fractures is obvious. A significant increase in operational activity over the past decades has clearly shown that one and all experts prefer the surgical method. The motive of the advantages of the surgical method is a complex of socio-economic factors [30]. About 2 million injuries are recorded every year in Ukraine, and as a result more than 150,000 bone surgeries are performed [31]. As a preoperative stage, as well as the main method of treatment in the presence of contraindications to surgery, skeletal traction is used. But one should not assume that surgical intervention will provide a positive solution to the quality and timing of treatment and rehabilitation of victims. The question of choosing the appropriate type of osteosynthesis and the quality of its implementation [32] is very relevant at this stage. When choosing a method of treatment, surgical access and method of fragments fixation, it is necessary to take into account all the features of the local and somatic status of a particular victim. The fixation of the fragments should, on the one hand, allow an early painless functional load on the limb, and on the other hand, it should be adequate during the whole period of the formation of a complete bone regenerate. In such situations, the choice is made between transosseous, bone and intramedullary osteosynthesis. However, each of these clamps, with its advantages, has several disadvantages.

The basic principles of restoring the integrity and function of the injured limb are the early use of rational treatment methods. The conditions for consolidation of such fractures are the matching of fragments with minimal traumatization and the timely use of stable functional osteosynthesis. This will give an opportunity to provide early loads on the operated limb with minimal risk of instability of bone fragments and restoration of the function of the injured limb in the shortest possible time. Currently, in the developed countries of the world, the technology of blocking intramedullary osteosynthesis (BIOS) is widely used for metal osteosynthesis, the main advantages of which are: low surgical access, reduced trauma of surgical interventions and intraoperative blood loss, biomechanically reasonable high stability of fixation 
of bone fragments, optimal implant placement from the standpoint of biomechanics of the limb $[12,33,34,35]$. In addition, its use provides a minimal cosmetic defect, helps to reduce by $2-3$ times the length of patient's stay in the hospital, allows the structure to be dynamized during the consolidation process and the early dosed load on the injured limb in the postoperative period, and creates conditions for active rehabilitation and quick patient return to active full life [36]. V.A. Sokolov et al. investigated the results of treatment of patients with diaphyseal fractures, depending on the use of osteosynthesis methods [36]. The victims who were osteosynthesized with external fixation devices and hybrid methods stayed in the hospital for the longest time. This was due to the need for inpatient care not only for the condition of the limb in the device, but also for conducting systematic daily exercises in therapeutic gymnastics. The shortest hospital stay was observed in patients undergoing osteosynthesis with blocking rods [37].

The principal advantages of intraosseous osteosynthesis from the standpoint of "biology" are due to the closed reposition of fragments and low surgical access outside the damage zone; no additional injury is caused to the tissues in the fracture zone and the periosteal blood supply is maintained [25].

\section{Errors and complications}

In the process of treating severe injuries of the musculoskeletal system, in some cases, for various reasons, the mistakes are made that negatively affect both the duration of treatment of patients and the final results. The severity of injuries, errors and complications arising in the process of treating these injuries, mainly worsen the results of treatment and make it difficult to rehabilitate the victims [38]. Of all medical errors, technical accounted for almost half, about $30 \%$ - errors in treatment tactics, about $15 \%$ - errors of a diagnostic nature, $5 \%$ - errors of conservative treatment [32]. Separately, it is necessary to study medical errors associated with medical activities. Such errors are made at all stages of treatment of patients, most often occur on the background of a significant severity of injury and constitute in the structure of primary disability from $20 \%$ to $32 \%$. The most common mistakes can be divided into tactical, technical and those that depend on the patient. Tactical errors include:

- underestimation of the severity and nature of the bone damage and the general condition of the victim;

- underestimation of damage to the skin of the limb;

- underestimation of the condition of the bone tissue - the use of the method of contraindications; - use of the method in unacceptable for it cases (when it is better to perform another type of ostesynthesis);

- the use of an incorrect type of blocking (static, dynamic or compression);

- non-compliance with the technology of intramedullary blocking osteosynthesis, making their own "amendments" during the operation, changing the course of surgical intervention;

- inadequate rehabilitation treatment and medical rehabilitation [39].

Errors of a technical nature during the osteosynthesis are the most common group, since the variety of clinical situations, technical support during the synthesis, the presence of the electron-optical converter (EOC), an orthopedic table and etc, the type of implant chosen, the method of performing (closed or open), the degree of achievement of reposition, the presence of bone fragments - creates a significant number of options for the occurrence of technical errors [22]. However, technical errors, despite their diversity, can be systematized and the most typical of them can be identified:

- incorrect or insufficient preoperative planning, which leads to the wrong choice of type (antegrade, reconstructive, retrograde, etc.) and the size of the rod or locking screws (too short or, on the contrary, long) [40].

- wrong point of rod insertion;

- excessive or insufficient penetration of the rod into the bone marrow canal, which can lead to the penetration of the rod into the joint cavity, and also creates difficulties in its removal;

- the refuse to use an open method of osteosynthesis (in the cases shown), as a result of which there may be an unsatisfactory reposition of fragments (especially for fragmental and segmental fractures);

- difficulties when locking the rod - misses into the holes, a fracture of the drill;

- mismatch of rod diameter to the diameter of the medullary canal, which can lead to crushing of the bones, the rejection of reaming a channel [41];

- incorrect or insufficient reposition of fragments, at which there are displacements (rotational, in length, angular);

- intraoperative detection of the spread of a fracture zone or an additional fracture of the segment that was not diagnosed in time, due to insufficient $\mathrm{x}$-ray examination;

- fracture of the bone at the site of the introduction of distal blocking screws as a result of repeated drilling during distal blocking [42];

- excessive trauma of own patellar ligament when administering the rod in the tibia and the 
patella during the retrograde introduction into the femoral bone;

- perforation of the bone wall with the rod;

- significant deformation of the locking screw during the compression blocking;

- insufficient hemostasis, damage to neurovascular formations (more often with distal blocking of the humerus) [43].

In the process of treatment and dynamic observation of the patient, it is necessary to take into account the human factor, since it is obvious that the final result of treatment depends on the implementation of recommendations and compliance with the orthopedic regimen. It is necessary to pay attention to the patient:

- the load on the operated limb;

- the rod dynamization in the cases shown in optimal terms;

- performing a control X-ray and examination by a doctor at regular intervals;

- lack of continuity at the stages of treatment (patients are consulted by doctors of clinics or central regional hospitals who cannot know all the nuances of this technique).

An incorrect load regimen on the operated limb, most often early and complete, can lead to a fracture of the locking screws or the rod and vice versa; a late and insufficient load on the limb quite often leads to violations of consolidation processes. Successfully performed intramedullary blocking osteosynthesis allows patients to use the operated limb practically from the first days, and within 1 to 2 months, which is optimal for dynamization (removal of the blocking screw) of the rod, fully load it. Therefore, patients quite often ignore the recommendations of the doctor on the dynamization of the rod and fall out of sight of health workers. And not timely or undone dynamization of the rod can lead to a fracture of the locking screw ("self-dynamization") and disruption of bone consolidation processes (slowing down the fracture fusion, the formation of a false joint, etc.) [44, 45]. Specific technical errors in performing osteosynthesis lead to specific complications, the clinical manifestations of which can vary from discomfort at the injection site of too long blocking screw to the impaired repair processes, anatomical and functional disorders, bone fracture at the site of numerous attempts at blocking or suppuration of the bone wound during a fracture of the drill. Severe common complication, which is inherent in this method is fat embolism.

G. Klimovitsky et al noted the following complications of the method: postoperative phlebitis of the lower limb $(2.1 \%)$, ligature fistulas $(4.2 \%)$, osteomyelitis $(2.1 \%)$, and fracture of the drill in the bone (10.6\%) [46]. Rusin et al. (2013) indicates that acute thrombosis in the inferior vena cava system is the most common disease that complicates the postoperative period. Phlebothrombosis in $25 \%$ of cases lead to pulmonary thromboembolism (PE), which in $12 \%$ of cases results in death and in $30 \%$ leads to severe disability [47].

As can be seen from the above, there is no single reason for the development of complications, therefore, there is no and cannot be one measure to prevent them. However, a balanced, thoughtful approach to diagnosis, the choice of treatment tactics and performing gentle, adequate operational techniques can be the main way to solve existing problems.

\section{Conclusions}

1. Blocking intramedullary osteosynthesis is a minimally invasive method that has certain advantages over other methods of surgical intervention, that optimize timing of consolidation, improve outcomes and patient quality of life during treatment, as well as it is the method of choice in the surgical treatment of diaphyseal fractures of long bones.

2. To achieve good results in treating patients using the method of blocking intramedullary osteosynthesis, it is necessary to adhere to clear indications for blocking osteosynthesis, plan surgery in detail, correctly select metal constructions, meticulously adhere to intervention technology.

\section{Funding}

The work was carried out in accordance with the research plan of Danylo Halytsky Lviv National Medical University.

\section{Conflict of interest}

The author declares that he has no conflict of interest.

\section{ЛИТЕРАТУРА}

1. Гайко ГВ, Деркач РВ. Аналіз причин і факторів, що зумовлюють смертність постраждалих із травмами опорно-рухового апарату, отриманими під час ДТП. Наука $і$ Практика. 2014;(1):82-86. http:// nbuv.gov.ua/UJRN/nauipr_2014_1_13

2. Гур'єв СО, Сацик СП, Свдошенко ВП, Нацевич PO. Лікування переломів довгих кісток у постраждалих унаслідок дорожньо-транспортних пригод. Травма. 2015;16(3):94-97. http://www.mif-ua.com/ archive/article/40906

3. Lacombe J, Cairns BJ, Green J, Reeves GK, Beral $\mathrm{V}$, Armstrong MEG. Million women study collaborators. the effects of age, adiposity, and physical activity on the risk of seven site-specific fractures in postmenopausal women. J Bone Miner Res. 2016 Aug;31(8):155968. doi: $10.1002 / \mathrm{jbmr} .2826$ 
4. Scholes S, Panesar S, Shelton NJ, Francis RM, Mirza S, Mindell JS, Donaldson LJ. Epidemiology of lifetime fracture prevalence in England: a population study of adults aged 55 years and over. Age and Ageing. 2014;43(2):234-40. doi:10.1093/ageing/aft167

5. Заруцький ЯЛ, Трутяк IP, Лакша АМ. Хірургічна тактика при пошкодженнях опорнорухового апарату у постраждалих із полі травмою. Літопис Травматологіï та Ортопедіï. 2011;(1-2):98-101. http://nbuv.gov.ua/UJRN/Lto_2011_1-2 24

6. Global Burden of Disease [Electronic resource]. WHO. [cited 2018 Dec 29]; Available from: http:// www.who.int/healthinfo/global_burden_disease/en/

7. Григор'єва НВ, Зубач ОБ. Фактори ризику переломів проксимального відділу стегнової кістки у хворих старших вікових груп. Травма. 2016;17(6):5361. doi:10.22141/1608-1706.6.17.2016.88618

8. Корж НА, Герасименко СИ, Климовицкий ВГ, Лоскутов АЕ, Романенко КK, Герасименко АС, Коломиец ЕН. Распространенность переломов костей и результаты их лечения в Украине (клиникоэпидемиологическое исследование). Opтопедия, Травматология и Протезирование. 2010;(3):5-14. https://cyberleninka.ru/article/n/rasprostranennostperelomov-kostey-i-rezultaty

9. Hettrich CM, Browner B. High-energy trauma. Best Pract Res Clin Rheumatol. 2012 Apr;26(2):281-88. doi: 10.1016/j.berh.2012.03.007

10. Борзых АВ, Климовицкий ВГ, Оприщенко АА Борзых НА, Басий РВ. Эпидемиология полиструктурной травмы конечностей в регионе Донбасса. Травма. 2013;14(6):61-63. http://www.mif-ua.com/ archive/article/37720

11. Benirschke SK, Melder I, Henley MB, Routt ML, Smith DG, Chapman JR, Swiontkowski MF. Closed interlocking nailing of femoral shaft fractures: assessment of technical complications and functional outcomes by comparison of a prospective database with retrospective review. J Ortop Trauma. 1993;7(2):11822. https://www.ncbi.nlm.nih.gov/pubmed/8459295

12. Chan R, Taylor BC, Gentile J. Optimal Management of High-Energy Pilon Fractures. Orthopedics. 2015 Aug;38(8):e708-14. doi: 10.3928/0147744720150804-59

13. Ditillo M, Pandit V, Rhee P, Aziz H, Hadeed S, Bhattacharya B, Friese RS, Davis K, Joseph B. Morbid obesity predisposes trauma patients to worse outcomes: a National Trauma Data Bank analysis. J Trauma Acute Care Surg. 2014 Jan;76(1):176-79. doi: $10.1097 /$ TA.0b013e3182ab0d7c

14. Корж МО, Танькут ВО. Медичні аспекти дорожньо-транспортної полі травми, як основно причини смертності молодих людей в Україні [Electronic resource]. [cited 2018 Dec 29]. Avialable from: http://eprints.kname.edu.ua/29868/1/4.pdf

15. Корж МО, Яременко ДО, Горідова ЛД, Романенко КК. Помилки та ускладнення в ортопедотравматологічній практиці. Ортопедия, Травматология и Протезирование. 2010;(2):5-10.

16. Заруцький ЯЛ, Косевцов ВО, Ткаченко АС. Травматизм у системі загроз національної безпеці України. Наука і Практика. 2014;(1):50-56. http:// opb.org.ua/3053/1

17. Vallier HA, Wang X, Moore TA, Wilber JH, Como JJ. Timing of orthopaedic surgery in multiple trauma patients: development of a protocol for early appropriate care. J Orthop Trauma. 2013 Oct;27(10):543-51. doi: 10.1097/BOT.0b013e31829efda1
18. Фаддеев ДИ. Осложнения при лечении множественных и сочетанных переломов длинных трубчастых костей методами раннего стабильного погружного и чрескостного остеосинтеза. Вестн Травматологии и Ортопедии. 2013;(1):18-23.

19. Brodauf L, Heßing K, Hoffmann R, Friemert B. Current state of medical care of polytrauma and mass casualty incidents in Germany: are we well-prepared? Unfallchirurg. 2015 Sep 1;118(10):890-900. doi: 10.1007/s00113-015-0063-2

20. Гурьев СЕ, Цвях АИ. Скелетная травма в структуре политравмы. Травма. 2014;15(5):7-10. http://www.mif-ua.com/archive/article/39982

21. Malisano LP, Stevens D, Hunter GA. The management of long bone fractures in the head-injured polytrauma patient. J Orthop Trauma. 1994;8(1):1-5. https://www.ncbi.nlm.nih.gov/pubmed/8169687

22. Шимон ВМ, Шерегій АА, Гелета ММ, Болдижар ММ. Погляди на лікування переломів кісток гомілки методом черезкісткового остеосинтезу в умовах ендемічних регіонів. Літопис Травматологіi ma Opmonediï. 2011;(21-22):180-82. http://nbuv.gov. ua/UJRN/Lto 2011 1-2 46

23. Шимон ВМ, Шерегій АА. Перспективні напрямки лікування діафізарних переломів кісток гомілки. Травма. 2010;11(4):363-66. http://www. mif-ua.com/archive/article/20004

24. Бруско АТ, Гайко ГВ. Сучасні уявлення про стадії реперативної регенерації кісткової тканини при переломах. Вісник Ортопедіï, Травматології. 2014;(2):5-8. http://www.irbis-nbuv.gov.ua/cgibin/irbis_nbuv/cgiirbis_64.exe?C21COM=2\&I21D $\mathrm{BN}=\mathrm{UJ} \overline{\mathrm{R}} \mathrm{N} \& \mathrm{P} 21 \mathrm{DBN}=\mathrm{UJRN} \& I M A G E$ FILE DOWNLOAD $=1 \&$ Image_file_name $=$ P $\bar{D} F / V_{0-}$ tip 2014_2 3.pdf

25. Климовицкий ВГ, Черныш ВЮ. Частота замедленной консолидации переломов у пострадавших разных возрастных групп и влияние на нее остеотропной терапии. Травма. 2011;12(3):129-35. http://www.mif-ua.com/archive/article/23297

26. Anuar-Ramdhan IM, Azahari IM, Med M. Minimally Invasive Plate Osteosynthesis with Conventional Compression Plate for Diaphyseal Tibia Fracture. Malays Orthop J. 2014;8(3):33-36. doi: 10.5704/ MOJ.1411.008

27. Maru N, Mandaliya D, Parmar R. Two stage reconstruction protocol in management of high-energy proximal tibia fractures (Schatzker, type IV-VI). J Evol Med Dent Sci. 2012;1(4):639-45. doi: 10.14260/ jemds $/ 100$

28. Butcher NE, Enninghorst N, Sisak K, Balogh ZJ. Definition of polytrauma: variable interrater versus intrarater agreement - a prospective international study among trauma surgeons. J Trauma Acute Care Surg. 2013;74(3):884-89. doi: 10.1097/TA.0b013e31827elbad.

29. Champion HR, Copes WS, Sacco WJ, Lawnick MM, Bain LW, Gann DS, Gennarelli T, Mackenzie E, Schwaitzberg S. A new characterization of injury severity. J Trauma. 1990 May;30(5):539-45.

30. Hoegel FW, Hoffmann S, Weninger P, Bühren V, Augat P. Biomechanical comparison of locked plate osteosynthesis, reamed and unreamed nailing in conventional interlocking technique, and unreamed angle stable nailing in distal tibia fractures. $J$ Trauma Acute Care Surg. 2012 Oct;73(4):933-38. doi: 10.1097/ TA.0b013e318251683f

31. Калашніков АВ, Ставінський ЮО. Алгоритм 
лікування розладів репаративного остеосинтезу після діафізарних переломів стегнової та великогомілкової кісток за допомогою блокуючого інтрамедулярного остеосинтезу. Травма. 2011;12(1):69-66. http:// www.mif-ua.com/archive/article/17224

32. Henderson CE, Lujan TJ, Kuhl LL, Bottlang M, Fitzpatrick DC, Marsh JL. 2010 mid-America Orthopaedic Association Physician in Training Award: healing complications are common after locked plating for distal femur fractures. Clin Orthop Relat Res. 2011 Jun;469(6):1757-65. doi: 10.1007/s11999-011-1870-6 33. Панков ИО, Сафаров РР, Сиразитдинов СД. Современные методы хирургического лечения пациентов с множественными переломами костей конечностей. Соврем Проблемы Науки и Образования. 2015;(5):243. https://www.science-education.ru/ru/ article/view? $\mathrm{id}=22352$

34. Paller DJ, Frenzen SW, Bartlett CS 3rd, Beardsley CL, Beynnon BD. A three-dimensional comparison of intramedullary nail constructs for osteopenic supracondylar femur fractures. J Orthop Trauma. 2013 Feb;27(2):93-99. doi: 10.1097/BOT.0b013e31825199c9 35. Lee YK, Chung CY, Park MS, Lee KM, Koo KH. Intramedullary nail versus extramedullary plate fixation for unstable intertrochanteric fractures: decision analysis. Arch Orthop Trauma Surg. 2013 Jul;133(7):961-68. doi: $10.1007 / \mathrm{s} 00402-013-1764-\mathrm{z}$

36. Kreb DL, Blokhuis TJ, van Wessem KJ, Bemelman M, Lansink KW, Leenen LP. Intramedullary nailing without interlocking screws for femoral and tibial shaft fractures. Arch Orthop Trauma Surg. 2013 Aug;133(8):1109-13. doi: 10.1007/s00402-013-1775-9

37. Соколов ВА, Бондаренко АВ, Бялик ЕИ, Файн АМ, Иванов ПА. Сравнительная оценка методов остеосинтеза при полисегментарных переломах нижних конечностей. Вестн Травматологии и $\mathrm{Op}$ топедии им НН Приорова. 2006;(4):3-8.

38. Дергачев ВВ, Александров АН, Ванхальский СБ, Онацкий ЮВ, Котенко РС, Колесников АМ. Интрамедуллярный блокирующий остеосинтез современная методика, новые сложности, осложнения. Травма. 2011;12(4):20-23. https://cyberleninka. $\mathrm{ru} / \mathrm{article} / \mathrm{n} /$ intramedullyarnyy-blokiruyuschiyosteosintez-sovremennaya-metodika-novye-slozhnostioslozhneniya

39. Березка МІ, Литовченко ВО, Гарячий ВО, Аль Масрі РАФ. Хірургічна технологія закритого інтрамедулярного блокуючого остеосинтезу при лікуванні постраждалих 3 багатоуламковими переломами кісток кінцівок. Проблеми Екологї̈ ma Медицини. 2011;15(5-6):3-8. https://cyberleninka. $\mathrm{ru} /$ article/n/hirurgichna-tehnologiya-zakritogointramedulyarnogo-blokuyuchogo-osteosintezu-prilikuvanni-postrazhdalih-z-bagatoulamkovimi

40. Півень ЮМ, Литвин ЮП. Передопераційне планування та вибір методу остеосинтезу при багатофрагментарних переломах проксимального відділу плечової кістки. Проблеми Травматології та Остеосинтезу. 2015;(1):75-76. http://nbuv.gov.ua/UJRN/ pto 2015138

41. Литовченко ВО, Власенко ДВ, Власенко ВГ, Гарячий ЕВ, Галабутська ТМ, Фадеїв ОГ. Інрамедулярний остеосинтез блокованими цвяхами в лікуванні переломів стегнової кістки в різних анатомо-функціональних утвореннях при одночасному пошкодженні. Травма. 2011;12(4):63-66. http://www.mif-ua.com/archive/article/25610

42. Челноков АН, Бекреев ДА. Интрамедул- лярный остеосинтез при переломах верхней трети большеберцовой кости - техника на основе чрезкостного остеосинтеза. Гений Ортопедии. 2011;(2):112-16. https://cyberleninka.ru/article/n/ intramedullyarnyy-osteosintez-pri-perelomah-verhneytreti-bolshebertsovoy-kosti-tehnika-na-osnovechreskostnogo-osteosinteza

43. Литовченко ВА, Березка НИ, Гарячий ЕВ, АФ Аль Масри Рами, Власенко ДВ. Ошибки при лечении многооскольчатых переломов костей конечностей с применением интрамедуллярного блокирующего остеосинтеза. Експериментальна і Клінічна Медицина. 2012; 4(57):132-135. http://nbuv.gov.ua/ UJRN/eikm $2012 \quad 4 \quad 31$

44. Литовченко ВО, Гарячий $\in \mathrm{B}$, Березка МI, Спесивий II. Інтрамедулярний блокуючий остеосинтез: помилки, яких не повинно бути. Медицина Сьогодні i Завтра. 2012;(1):113-19. https://msz.knmu.edu.ua/? journal $=$ pub $\&$ page $=$ article $\&$ op $=$ viewFile $\&$ path $\% 5 \mathrm{~B} \% 5$ $\mathrm{D}=223 \&$ path\%5B $\% 5 \mathrm{D}=209$

45. Литовченко ВО, Гарячий СB, Березка МI, Спесивий II.Найпоширеніші помилки при використані інтрамедулярного блокуючого остеосинтезу. Травма. 2012;13(4):145-48. http://www.mif-ua.com/ archive/article/34672

46. Климовицкий ВГ, Черныш ВЮ, Климовицкий ФВ. Наружный чрескостный остеосинтез при лечении внесуставных переломов костей голени: показания, осложнения, результаты применения. Травма. 2016;17(2):26-30. http://www.mif-ua.com/ archive/article/42580

47. Русин ВI, Попович ЯМ, Корсак ВВ, Болдіжар ПО. Радіоізотопна діагностика глибоких венозних тромбозів. Науковий вісник Уэсгородського університету. Сер Медицина. 2013;1(46):114-17. http://nbuv.gov.ua/UJRN/UNUMED_2013_1_26

\section{REFERENCES}

1. Gaiko GV, Derkach RV. Cause analysis and study of the reasons that influence the mortality rate in a car accident victims with the injuries to the musculoskeletal system. Nauka i Praktika. 2014;(1):82-86. http://nbuv. gov.ua/UJRN/nauipr_2014_1_13 (in Ukr.)

2. Gur'€v SO, Satsik SP, Evdoshenko VP, Natsevich RO. Likuvannia perelomiv dovgikh kistok u postrazhdalikh unaslidok dorozhn'o-transportnikh prigod. Travma. 2015;16(3):94-97. http://www.mif-ua.com/archive/article/40906 (in Ukr.)

3. Lacombe J, Cairns BJ, Green J, Reeves GK, Beral $\mathrm{V}$, Armstrong MEG. Million women study collaborators. The effects of age, adiposity, and physical activity on the risk of seven site-specific fractures in postmenopausal women. J Bone Miner Res. 2016 Aug;31(8):155968. doi: $10.1002 / \mathrm{jbmr} .2826$

4. Scholes S, Panesar S, Shelton NJ, Francis RM, Mirza S, Mindell JS, Donaldson LJ. Epidemiology of lifetime fracture prevalence in England: a population study of adults aged 55 years and over. Age and Ageing. 2014;43(2):234-40. doi:10.1093/ageing/aft167

5. Zarutsky J, Trutiak I, Laksha A. Surgical tactics in injuries of the locomotor apparatus in patients with multiple injuries. Litopis Travmatologii ta Ortopedii. 2011;(1-2):98-101.

Lto_2011_1-2_24 (in Ukr.)

6. Global Burden of Disease [Electronic resource]. WHO. [cited 2018 Dec 29]; Available from: http:// www.who.int/healthinfo/global_burden_disease/en/ 
7. Grygorieva NV, Zubach OB. Riskfactors of proximal hip fractures in older patients. Travma. 2016;17(6):5361. doi:10.22141/1608-1706.6.17.2016.88618 (in Ukr.) 8. Korzh NA, Gerasimenko SI, Klimovitskii VG, Loskutov AE, Romanenko KK, Gerasimenko AS, Kolomiets EN. Rasprostranennost' perelomov kostei i rezul'taty ikh lecheniia v Ukraine (kliniko-epidemiologicheskoe issledovanie). Ortopediia, Travmatologiia $i$ Protezirovanie. 2010;(3):5-14. https://cyberleninka.ru/ article/n/rasprostranennost-perelomov-kostey-i-rezultaty (in Ukr.)

9. Hettrich CM, Browner B. High-energy trauma. Best Pract Res Clin Rheumatol. 2012 Apr;26(2):281-88. doi: 10.1016/j.berh.2012.03.007

10. Borzykh AV, Klimovitsky VG, Oprischenko AA, Borzykh NA, Basiy RV. Epidemiology of polystructural trauma of the extremities in the Donbass region. Travma. 2013;14(6):61-63. http://www.mif-ua.com/archive/article/37720 (in Russ.)

11. Benirschke SK, Melder I, Henley MB, Routt ML, Smith DG, Chapman JR, Swiontkowski MF. Closed interlocking nailing of femoral shaft fractures: assessment of technical complications and functional outcomes by comparison of a prospective database with retrospective review. J Ortop Trauma. 1993;7(2):11822. https://www.ncbi.nlm.nih.gov/pubmed/8459295

12. Chan R, Taylor BC, Gentile J. Optimal Management of High-Energy Pilon Fractures. Orthopedics. 2015 Aug;38(8):e708-14. doi: 10.3928/0147744720150804-59

13. Ditillo M, Pandit V, Rhee P, Aziz H, Hadeed S, Bhattacharya B, Friese RS, Davis K, Joseph B. Morbid obesity predisposes trauma patients to worse outcomes: a National Trauma Data Bank analysis. J Trauma Acute Care Surg. 2014 Jan;76(1):176-79. doi: 10.1097/TA.0b013e3182ab0d7c

14. Korzh MO, Tan'kut VO. Medichni aspekti dorozhn'o-transportnoï poli travmi, iak osnovnoï prichini smertnosti molodikh liudei v Ukraïni [Electronic resource]. [cited 2018 Dec 29]. Avialable from: http:// eprints.kname.edu.ua/29868/1/4.pdf (in Ukr.)

15. Korzh MO, Iaremenko DO, Goridova LD, Romanenko KK. Pomilki ta uskladnennia v ortopedotravmatologichnii praktitsi. Ortopediia, Travmatologiia $i$ Protezirovanie. 2010;(2):5-10. (in Ukr.)

16. Zarutskyi YL, Kosevtsov VO, Tkachenko AE. Traumatism in the system of threats to the ukrainian national security. Nauka i Praktika. 2014;(1):50-56. http://opb.org.ua/3053/1(in Ukr.)

17. Vallier HA, Wang X, Moore TA, Wilber JH, Como JJ. Timing of orthopaedic surgery in multiple trauma patients: development of a protocol for early appropriate care. J Orthop Trauma. 2013 Oct;27(10):543-51. doi: 10.1097/BOT.0b013e31829efda1

18. Faddeev DI. Oslozhneniia pri lechenii mnozhestvennykh i sochetannykh perelomov dlinnykh trubchastykh kostei metodami rannego stabil'nogo pogruzhnogo i chreskostnogo osteosinteza. Vestn Travmatologii $i$ Ortopedii. 2013;(1):18-23 (in Russ.)

19. Brodauf L, Heßing K, Hoffmann R, Friemert B. Current state of medical care of polytrauma and mass casualty incidents in Germany: are we well-prepared? Unfallchirurg. 2015 Sep 1;118(10):890-900. doi: 10.1007/s00113-015-0063-2

20. Gur'ev SE, Tsviakh AI. Skeletnaia travma v strukture politravmy. Travma. 2014;15(6):7-10. http:// www.mif-ua.com/archive/article/39982 (in Russ.)

21. Malisano LP, Stevens D, Hunter GA. The man- agement of long bone fractures in the head-injured polytrauma patient. J Orthop Trauma. 1994;8(1):1-5. https://www.ncbi.nlm.nih.gov/pubmed/8169687

22. Shimon VM, Sheregii AA, Geleta MM, Boldizhar MM. Pogliadi na likuvannia perelomiv kistokgomilki metodom cherezkistkovogo osteosintezu v umovakh endemichnikh regioniv. Litopis Travmatologii ta Ortopedii. 2011;(21-22):180-82. http://nbuv.gov.ua/ UJRN/Lto_2011_1-2_46 (in Ukr.)

23. Shimon VM, Sheregii AA. Perspektivni napriamki likuvannia diafizarnikh perelomiv kistokgomilki. Travma. 2010;11(4):363-66. http://www.mif-ua.com/archive/article/20004 (in Ukr.)

24. Brusko AT, Gaiko GV. Modern concepts of stages of bone tissue fractures reparative regeneration. Visnik Ortopedii, Travmatologii. 2014;(2):5-8. http://www. irbis-nbuv.gov.ua/cgi-bin/irbis_nbuv/cgiirbis_64.exe?C $21 \mathrm{COM}=2 \& I 21 \mathrm{DBN}=\mathrm{UJRN} \& \mathrm{P} 21 \mathrm{DBN}=\mathrm{UJR} \overline{\mathrm{T}} \& \mathrm{IMA}$ GE_FILE_DOWNLOAD $=1 \&$ Image_file_name $=P D F /$ Votip_2014__2_3.pdf (in Ukr.)

25. Klimovitskii VG, Chernysh VIu. Chastota zamedlennoi konsolidatsii perelomov $\mathrm{u}$ postradavshikh raznykh vozrastnykh grupp i vliianie na nee osteotropnoi terapii. Travma. 2011;12(3):129-35. http://www. mif-ua.com/archive/article/23297 (in Russ.)

26. Anuar-Ramdhan IM, Azahari IM, Med M. Minimally invasive plate osteosynthesis with conventional compression plate for diaphyseal tibia fracture. Malays Orthop J. 2014;8(3):33-36. doi: 10.5704/MOJ.1411.008 27. Maru N, Mandaliya D, Parmar R. Two stage reconstruction protocol in management of high-energy proximal tibia fractures (Schatzker, type IV-VI). $J$ Evol Med Dent Sci. 2012;1(4):639-45. doi: 10.14260/ jemds $/ 100$

28. Butcher NE, Enninghorst N, Sisak K, Balogh ZJ. Definition of polytrauma: variable interrater versus intrarater agreement - a prospective international study among trauma surgeons. J Trauma Acute Care Surg. 2013;74(3):884-89. doi: 10.1097/TA.0b013e31827elbad. 29. Champion HR, Copes WS, Sacco WJ, Lawnick MM, Bain LW, Gann DS, Gennarelli T, Mackenzie E, Schwaitzberg S. A new characterization of injury severity. J Trauma. 1990 May;30(5):539-45.

30. Hoegel FW, Hoffmann S, Weninger P, Bühren $\mathrm{V}$, Augat P. Biomechanical comparison of locked plate osteosynthesis, reamed and unreamed nailing in conventional interlocking technique, and unreamed angle stable nailing in distal tibia fractures. J Trauma Acute Care Surg. 2012 Oct;73(4):933-38. doi: 10.1097/TA. 0b013e318251683f

31.Kalashnikov AV, Stavinsky YuA. Treatment algorithm for reparative osteogenesis disorders after femoral and tibia diaphyseal fractures with blocking intramedullary osteosynthesis. Travma. 2011;12(1):69-66. http:// www.mif-ua.com/archive/article/17224 (in Ukr.)

32. Henderson CE, Lujan TJ, Kuhl LL, Bottlang M, Fitzpatrick DC, Marsh JL. 2010 mid-America Orthopaedic Association Physician in Training Award: healing complications are common after locked plating for distal femur fractures. Clin Orthop Relat Res. 2011 Jun;469(6):1757-65. doi: 10.1007/s11999-011-1870-6

33. Pankov IO, Safarov RR, Sirazitdinov SD. Modern method of the surgical treatment of patient with polyfractures of extremyties. Sovrem Problemy Nauki i Obrazovaniia. 2015;(5):243. https://www.science-education.ru/ru/article/view?id=22352 (in Russ.)

34. Paller DJ, Frenzen SW, Bartlett CS 3rd, Beardsley CL, Beynnon BD. A three-dimensional compari- 
son of intramedullary nail constructs for osteopenic supracondylar femur fractures. J Orthop Trauma. 2013 Feb;27(2):93-99. doi: 10.1097/BOT.0b013e31825199c9 35. Lee YK, Chung CY, Park MS, Lee KM, Koo KH. Intramedullary nail versus extramedullary plate fixation for unstable intertrochanteric fractures: decision analysis. Arch Orthop Trauma Surg. 2013 Jul;133(7):961-68. doi: $10.1007 / \mathrm{s} 00402-013-1764-\mathrm{z}$

36. Kreb DL, Blokhuis TJ, van Wessem KJ, Bemelman M, Lansink KW, Leenen LP. Intramedullary nailing without interlocking screws for femoral and tibial shaft fractures. Arch Orthop Trauma Surg. 2013 Aug;133(8):1109-13. doi: 10.1007/s00402-013-1775-9 37. Sokolov VA, Bondarenko AV, Byalik EI, Fain AM, Ivanov PA. Comparative assessment of osteosynthesis techniques in polysegmental fractures of lower extremities. Vestn Travmatologii $i$ Ortopedii im NN Priorova. 2006;(4):3-8. (in Russ.)

38. Dergachov VV, Aleksandrov AN, Vankhaisky SB, Onatsky YuV, Kotenko RS, Kolesnikov AM. Locking intramedullary nailing-modern method, new difficulties, complications .Travma. 2011;12(4):20-23. https:// cyberleninka.ru/article/n/intramedullyarnyy-blokiruyuschiy-osteosintez-sovremennaya-metodika-novyeslozhnosti-oslozhneniya (in Ukr.)

39. Berezka MI, Litovchenko VO, Garyachiy VO, Rami AF, Al-Masri. Surgical technology for closed intramedullary osteosynthesis during the treatment of patients with multifragmental fractures of limb bones. Problemi Ekologii ta Meditsini. 2011;15(5-6):3-8. https:// cyberleninka.ru/article/n/hirurgichna-tehnologiya-zakritogo-intramedulyarnogo-blokuyuchogo-osteosintezu-prilikuvanni-postrazhdalih-z-bagatoulamkovimi (in Ukr.) 40. Piven' IuM, Litvin IuP. Peredoperatsiine planuvannia ta vibir metodu osteosintezu pri bagatofragmentarnikh perelomakh proksimal'nogo viddilu plechovoï kistki. Problemi Travmatologii ta Osteosintezu. 2015;(1):75-76. http://nbuv.gov.ua/UJRN/ pto_2015_1_38 (in Ukr.)

41. Litovchenko VO, Vlasenko DV, Vlasenko

\section{Адрес для корреспонденции}

79010, Украина, г. Львов,

ул. Пекарская, д. 69,

Львовский национальный медицинский

университет имени Данила Галицкого,

кафедра медицины катастроф

и военной медицины,

тел. +38 (032) 260-08-28,

e-mail: kozopas@ukr.net,

Козопас Виктор Степанович

\section{Сведения об авторах}

Козопас Виктор Степанович, к.м.н., ассистент кафедры медицины катастроф и военной медицины, Львовский национальный медицинский университет имени Данила Галицкого, г. Львов, Украина. https://orcid.org/0000-0003-3451-6016

\section{Информация о статье}

Поступила 6 мая 2018 г.

Принята в печать 14 января 2019 г.

Доступна на сайте 30 апреля 2019 г.
VG, Jaryachiy EV, Galabuts'ka TM, Fadeïv OG. Inrameduliarnii osteosintez blokovanimi tsviakhami $\mathrm{v}$ likuvanni perelomiv stegnovoï kistki $\mathrm{v}$ riznikh anatomo-funktsional'nikh utvorenniakh pri odnochasnomu poshkodzhenni. Travma. 2011;12(4):63-66. http:// www.mif-ua.com/archive/article/25610 (in Ukr.)

42. Chelnokov AN, Bekreyev DA. Intramedullary osteosynthesis for fractures of the upper tibial third a technique based on transosseous osteosynthesis $\mathrm{Ge}$ nii Ortopedii. 2011;(2):112-16. https://cyberleninka.ru/ article/n/intramedullyarnyy-osteosintez-pri-perelomahverhney-treti-bolshebertsovoy-kosti-tehnika-na-osnovechreskostnogo-osteosinteza (in Russ.)

43. Litovchenko VO, Berezka MI, Garyachiy EV, Rami AF, Al Masri, Vlasenko DV. Mistakes during treatment of multi-fragment fractures of limbs' bones by implementation of intramedullar blocking ostheosynthesis. Eksperimental'na $i$ Klinichna Meditsina. 2012; 4(57):132-135. http://nbuv.gov.ua/UJRN/ eikm_2012_4_31 (in Russ.)

44. Litovchenko VA, Garyachiy EV, Berezka MI, Spesiviy II. Intramedullary locking osteosynthesis: errors which should not be. Meditsina S'ogodni i Zavtra. 2012;(1):113-19. https://msz.knmu.edu.ua/?journal=p ub\&page $=$ article \&op $=$ viewFile \&path $\% 5 B \% 5 \mathrm{D}=223 \& \mathrm{p}$ ath $\% 5 \mathrm{~B} \% 5 \mathrm{D}=209$ (in Ukr.)

45. Lytovchenko VA, Jaryachiy YeV, Berezka MI, Spesiviy II. Most common mistakes while using locked intramedullary nailing. Travma. 2012;13(4):145-48. http:// www.mif-ua.com/archive/article/34672 (in Ukr.)

46. Klimovitsky VH, Chernysh VYu, Klimovitsky FV. External transosseous osteosynthesis in treatment of tibia extraarticular fracture: indications, complications, results. Travma. 2016;17(2):26-30. http://www.mifua.com/archive/article/42580 (in Russ.)

47. Rusyn VI, Popovych YM, Korsak VV, Boldizhar PO. Radioisotope diagnosis deep venous thrombosis. Naukovii Visnik Uzhgorods'kogo Universitetu. Ser Meditsina. 2013;1(46):114-17. http://nbuv.gov.ua/UJRN/ UNUMED_2013_1_26 (in Ukr.)

\section{Address for correspondence}

79010, Ukraine,

Lviv, Pekarskaya Str., 69,

Danylo Halytsky Lviv National

Medical University,

Department of Disaster Medicine

And Military Medicine,

Tel. +38 (032) 260-08-28,

e-mail: kozopas@ukr.net,

Viktor S. Kozopas

\section{Information about the authors}

Kozopas Viktor S., PhD, Assistant of the Department of Disaster Medicine and Military Medicine, Danylo Halytsky Lviv National Medical University, Lviv, Ukraine.

https://orcid.org/0000-0003-3451-6016

\section{Article history}

Arrived 06 May 2018

Accepted for publication 14 January 2019 Available online 30 April 2019 